\title{
ABNORMAL VOLUME TRADED AS AN INDICATION OF INSIDER TRADING IN JSE LISTED COMPANIES
}

\author{
K Thaver and M Ward*
}

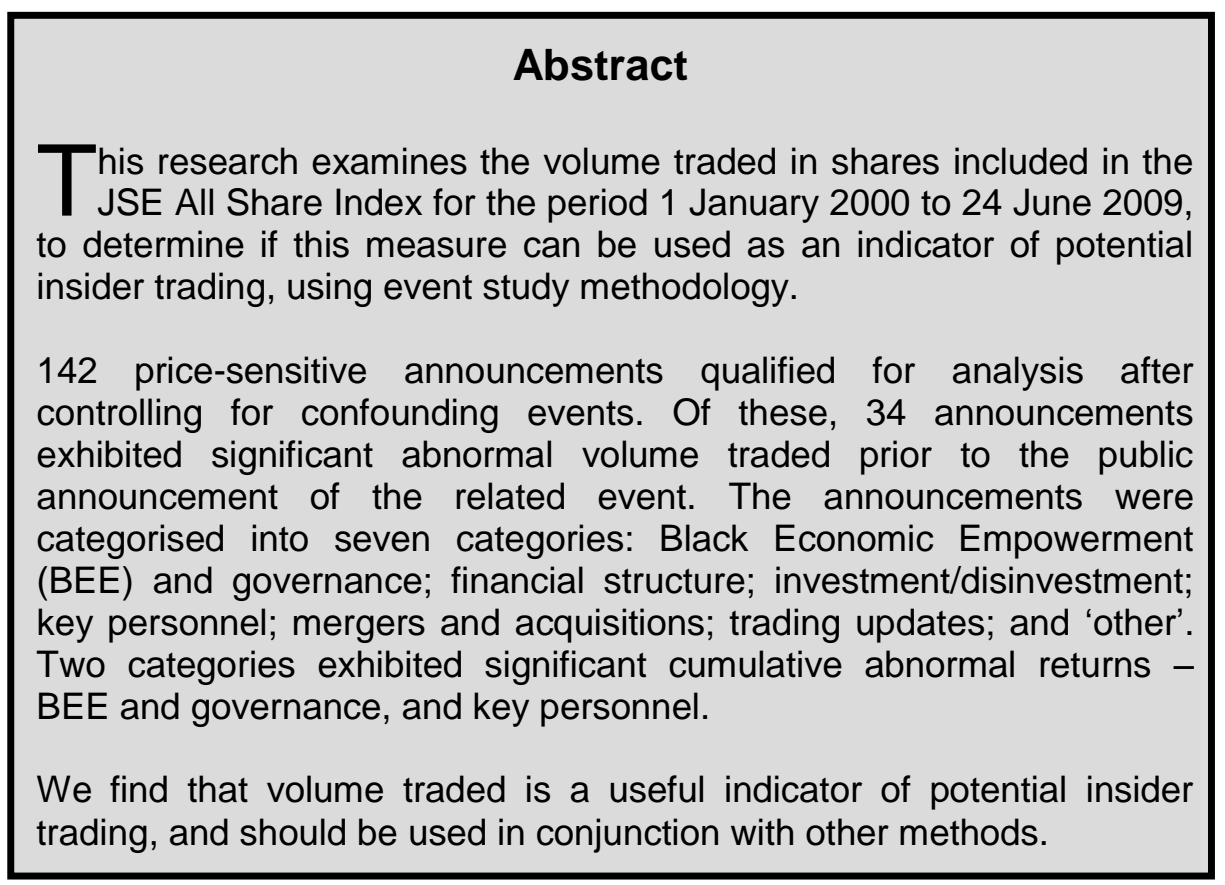

\section{Introduction}

Bhattacharya and Daouk (2002) state that it is relatively easy to establish insider trading laws, but much more difficult to enforce these laws. They find that there have been prosecutions in only 38 of the 87 countries that have insider trading laws. Furthermore, they note that differences between the developed and emerging markets are stark, with prosecutions in 82 percent of developed countries, versus only 25 percent for emerging markets.

The Securities Services Act 36 of 2004 (RSA, 2004) legislates and controls against insider trading (which is listed as a criminal offence). The Act further stipulates that the Financial Services Board (FSB) is responsible for the investigation and civil prosecution of insider trading activities, amongst other things (RSA, 2004). However, the possibility of prosecution does not deter some insiders from

\footnotetext{
* Gordon Institute of Business Science, University of Pretoria, Republic of South Africa.

Email: mchlwrd@gmail.com
} 
practising insider trading, as the rewards of self-enrichment and personal gain often outweigh the risks of being caught.

In South Africa there have been relatively few examples of insider trading cases that have been investigated. The FSB reported that up to September 2008 it had investigated 95 cases of insider trading, of which 69 were concluded. One case had been referred to the Attorney General for consideration, and ten resulted in the intent to proceed with civil action. Nine of these were settled out of court and the remaining one was proceeding as a civil action (FSB, 2009). This evidence highlights the difficulty in identifying and prosecuting insider trading activities.

The aim of this research is to investigate whether abnormal trading volumes precede significant announcements on JSE listed companies, and if so, are these indicative of insider trading activities?

\section{Literature review}

Although various international studies have investigated the impact of insider trading using volume traded, the quantity of research in this area is much lower than that conducted on abnormal returns (Ajinkya and Jain, 1989). Some researchers have considered abnormal volume traded in conjunction with abnormal returns (Meulbroek, 1992; Ryan and Taffler, 2004; Jarrell and Poulsen, 1989; and Ascioglu, McInish and Wood, 2002). Meulbroek (1992) considered abnormal volume traded as a step to calculating abnormal returns.

Most researchers have noted the existence of abnormally high volume traded prior to significant announcements. Meulbroek (1992) found that the total volume traded on the days preceding significant announcements was higher than expected. She further found that insiders were responsible for most of the unusual trading volume. Keown and Pinkerton (1981) found that the volume traded increased significantly in the period leading up to a merger announcement, and stated that this could be explained if relevant information had leaked.

Jarrell and Poulsen (1989) found that in successful bids relating to mergers or acquisitions, there were significant stock-price run-ups and surges in volume before the bids. Ascioglu, McInish and Wood (2002) found that significant increases in volume traded occurred from about four days prior to a merger announcement. In contrast, a study by Sanders and Zdanowicz (1992) found that while there was evidence of stock-price run-ups before an announcement, there was no evidence of abnormal trading volume. They also found no evidence to link information leaked to insider trading.

Arnold, Erwin, Nail and Nixon (2006) found that there was significant abnormal volume traded prior to announcements. They also concluded that where options on stocks were traded, the options displayed abnormal volumes of trades earlier than the underlying shares. This finding was corroborated by Jayaraman, Frye and Sabherwal (2001), and Cao, Chen and Griffin (2005). 
Two categories of announcements can be analysed: scheduled and unscheduled announcements (Chae, 2005). The timing of scheduled announcements is publicly known; for example, earnings announcements are typically scheduled announcements. Unscheduled announcements include acquisitions, bond-rating announcements, changes in directors etc., for which the timing, magnitude, and price impact are not publicly known. Chae (2005) investigated the impact on trading volume prior to scheduled and unscheduled announcements, and concluded that trading volume actually decreased significantly before scheduled announcements and increased significantly before unscheduled announcements. This finding on the impact of scheduled announcements concurred with that of Morse (1981, p. 382), who concluded that there was "a definite lack of activity in the stock market in anticipation of the earnings announcement".

Mergers and acquisitions are cited as significant announcements (i.e. likely to have a price impact on shares) by Jarrell and Poulsen (1989), Ascioglu et al. (2002), Keown and Pinkerton (1981), Sanders and Zdanowicz (1992), and Arnold et al. (2006). Annual general meetings and earnings announcements were identified as significant announcements by Morse (1981) and Wong Kie, Sequeira and McAleer (2005). Similarly, the release of analysts' reports can impact share prices and volume traded (Chordia, Subrahmanyam and Anshuman, 2001).

Ryan and Taffler (2004) considered the following announcements to have a significant impact on volume traded: analysts; share deals; director share dealings; bids; preliminary results; interim results; and financing issues. Fidrmuc, Goergen and Renneboog's (2006) selection of significant announcements included: change of CEO; change in executive directors; change in non-executive directors; mergers and acquisitions; asset disposals; capital structure changes; future prospects; and business events.

Meulbroek (1992) listed different types of significant insider information: that which was takeover related; earnings related (negative and positive); bankruptcy or financial fraud related, as well as miscellaneous news (good and bad). Givoly and Palmon (1985) cited earnings announcements; management forecasts; dividend news; operational plans; and other events as significant events.

\section{Research hypothesis}

The literature review concluded that increased trading was more prevalent with unscheduled announcements than scheduled announcements, and consequently, this study only investigates unscheduled announcements. The null hypothesis states that there is no significant positive average daily cumulative abnormal volume turnover (ACAVT) in shares traded prior to a company making an unscheduled announcement. A one-tailed significance test at a 5\% significance level is used.

\section{Research methodology}

As with the analysis of share price returns, volume traded can be analysed using the actual volume traded or after a logarithmic transformation. A logarithmic 
transformation has the advantage of transforming the distribution of daily volume traded into an approximately normally distributed variable, and thus increasing the quality of statistical analysis (Ajinkya and Jain, 1989). Many researchers have followed this approach (Meulbroek, 1992; Ascioglu et al., 2002; Sanders and Zdanowicz, 1992; Jayaraman, Frye and Sabherwal 2001; and Chae, 2005).

Meulbroek (1992) used a regression equation to compute abnormal volume traded for each stock. The regression equation included, as predictor variables, a market index, and dummy variables relating to the days of the week, announcements, inside trades and news items. Further, Meulbroek (1992) used the Securities and Exchange Commission's (SEC's) confirmed insider trading data as the basis of her study. Since the proven occurrence of insider trading activity in South Africa is very low (only one conviction), her approach could not be followed in this study.

Ascioglu et al., (2002), Sanders and Zdanowicz (1992) and Arnold et al. (2006) all used an event study methodology. In each case, they designated $t_{0}$ as the day of the announcement and stipulated an event window of varying numbers of days prior to this. They calculated the benchmark for normal daily volume traded by taking the mean of the volume traded over a period of between 50 and 210 days prior to the event window. This benchmark value was then compared to the volume traded in the event window to determine if there was any abnormal volume traded using various statistical methods.

Chae (2005) used log turnover as a basis for measuring volume traded, and corrected for the number of outstanding shares. His approach was followed in this paper, as the standardisation for shares outstanding made it superior to the others.

The study analysed publicly available Johannesburg Securities Exchange (JSE) daily share trading data, to identify significant announcements and make statistical inferences on pre-announcement abnormal volume traded as a possible indicator of insider trading activities. It consisted of three phases. In phase one, any significant abnormal price movements were identified; in phase two the volume traded prior to these announcements was analysed; and in phase three the analysis was repeated using a bootstrapping approach to compensate for non-normality. Possible insider trading activities were identified by establishing if statistically significant abnormal volumes were traded in the preannouncement period, when compared to the calculated benchmark. Phase one of the analysis was conducted on share price returns, whilst phases two and three used the volume traded.

The announcements identified in phase one were grouped into seven categories (BEE and governance; financial structure; investment or disinvestment; key personnel; mergers and acquisitions; trading update; and other). This enabled the testing of sub-hypotheses relating to each category in order to establish which types of unscheduled announcements were more commonly preceded by possible insider trading and if there were differences in the magnitude of the preannouncement activities. 
For phase one the sample consisted of all companies included in the JSE All Share Index (ALSI) on 24 June 2009. The ALSI contains approximately 160 companies listed on the JSE, and represents over 99 percent of the market capitalisation. The data for the above population was analysed from 01 January 2000 to 24 June 2009. For phases two and three, the sample consisted of the significant announcements identified in phase 1 .

The study corrected for confounding events as recommended by van der Plas (2007) and McWilliams and Siegel (1997). Confounding events were unrelated events that could have a material impact on the share price of the company, which occurred in the event window.

A difference between means or medians test was performed between the categories for phases two and three. The means or medians of each category were compared with the means or medians of the other categories to determine if there were significant differences between categories.

The McGregor BFANet Analyser price database was used to obtain general information relating to JSE listed companies: daily share prices, daily volume traded and daily outstanding shares (McGregor BFANet, 2009b). Security Exchange News Service (SENS) announcements from the JSE were used to identify announcements and confounding events. These were obtained from the McGregor BFA Analyser News Module of McGregor BFANet (2009a) and the www.imaraspreid.co.za website of Imara SP Reid (2009).

For phase one it was necessary to calculate daily returns, and model the daily benchmark expected returns. The abnormal returns were determined from the difference between the two. Two methods of determining abnormal returns were considered for this study, namely the Capital Asset Pricing Model (CAPM) and the control portfolio approach. Ultimately, the control portfolio approach was selected, as it provides a number of advantages over the CAPM; in particular, it considers the unique factors (size, value and the resource effect) that have been shown to be significant on the JSE (Mordant and Muller, 2003).

The event study model ("event engine") developed by Muller and Ward (2009) was utilised to identify the days, in the 10 year sample period, with the top five abnormal returns for each of the shares listed on the JSE ALSI.

Muller and Ward (2009) constructed their control portfolios by placing each market effect into one of two or three states: a share's size was small, medium, or large; a share was either a value or a growth share; finally, a stock was classified as either resource or non-resource. These market effects were used to construct the twelve control portfolios, as displayed in Table 1 below. 
Table 1: Twelve factor-mimicking control portfolios

\begin{tabular}{l|l}
\hline Key & $\begin{array}{c}\text { Description of Control Portfolio in terms of: } \\
\text { (MarketCap, Value or Growth, Resources or NonResources) }\end{array}$ \\
\hline LVR & Large, Value, Resources \\
\hline LVN & Large, Value, Non-resources \\
\hline LGR & Large, Growth, Resources \\
\hline LGN & Large, Value, Non-resources \\
\hline MVR & Medium, Value, Resources \\
\hline MVN & Medium, Value, Non-resources \\
\hline MVN & Medium, Growth, Resources \\
\hline MGN & Medium, Value, Non-resources \\
\hline SVR & Small, Value, Resources \\
\hline SVN & Small, Value, Non-resources \\
\hline SGR & Small, Growth, Resources \\
\hline SGN & Small, Growth, Non-resources \\
\hline
\end{tabular}

Muller and Ward (2009) calculated the 12 betas for each share against the 12 control portfolio indices, and used these to estimate expected returns, after controlling for survivorship bias by re-balancing quarterly to include new listings and drop de-listed companies. It must be noted that four years of start-up data (1 Jan 1996 to 31 Dec 1999) were required to determine the betas. Therefore, events in this period were ignored in this study.

The dates associated with the top five abnormal returns for each company in the sample were used to identify the appropriate SENS announcement using the following rules:

- The date of the closest significant SENS announcement was designated $t_{0}$.

- If the abnormal return occurred within the 21 day period prior to (or on) the SENS announcement date (i.e. $t_{-21}-t_{0}$ ), it was included in the analysis. If it occurred earlier than this, it was ignored.

- If the abnormal return occurred within three trading days after the SENS announcement (i.e. $t_{0}-t_{3}$ ), it was included in the analysis. If it occurred after this, it was ignored.

- Any announcements that contained confounding events in the period used to detect abnormal volume traded (i.e. $\mathrm{t}_{-21}-\mathrm{t}_{0}$ ) were omitted from the sample.

The final task of the data analysis for phase one was to categorise the announcements. The different announcement types were constituted into different sub-samples, and were analysed individually as well as collectively.

The average daily cumulative abnormal volume traded (ACAVT) was then calculated for the complete sample, and subsequently for each sub-sample, according to the following rules: 
- The log turnover was a natural logarithmic measure of the volume traded, correcting for the number of outstanding shares.

- The log expected turnover (EVT) was the mean log turnover calculated for the period $\mathrm{t}_{-84}$ to $\mathrm{t}_{-22}$ (a period of 63 trading days, which was roughly equivalent to three calendar months).

- Abnormal volume turnover (AVT) was calculated by subtracting the log expected turnover from the log turnover.

- The pre-announcement period to check for average daily cumulative abnormal volume turnover (ACAVT) was from $t_{-21}$ to $t_{-1}$. ACAVT was calculated by averaging AVT over this period. This was a period of approximately one calendar month before the announcement and consistent with van der Plas (2007).

- The total event window for consideration was 86 trading days (approximately equivalent to four calendar months).

The model proposed by Chae (2005) was adapted to measure the volume traded, as illustrated in the equations below.

Log turnover

$\tau_{\mathrm{i}, \mathrm{t}}=\ln \left(\frac{\text { Trading Volume }_{\mathrm{i}, \mathrm{t}}}{\text { Outstanding Shares }_{\mathrm{i}, \mathrm{t}}}\right)$

Log expected turnover

$\bar{\tau}_{\mathrm{i}, \mathrm{t}}=\left(\frac{\sum_{\mathrm{t}=-84}^{\mathrm{t}=-22} \tau_{\mathrm{i}, \mathrm{t}}}{63}\right)$

Abnormal turnover $\left(\xi_{i, t}\right)=\log$ turnover $-\log$ expected turnover

$\xi_{\mathrm{i}, \mathrm{t}}=\tau_{\mathrm{i}, \mathrm{t}}-\bar{\tau}_{\mathrm{i}, \mathrm{t}}$

Average daily cumulative abnormal volume turnover (ACAVT)

$\operatorname{ACAVT}=\frac{\left(\sum_{\mathrm{t}=-12}^{\mathrm{t}=-1} \xi_{\mathrm{i}, \mathrm{t}}\right)}{21}$

where

$\mathrm{i}=$ the share under consideration

$\mathrm{t}=$ event time in days

Average daily percentage abnormal volume traded (APAV)

$\mathrm{APAV}=\left(\mathrm{e}^{\mathrm{ACAVT}}-1\right) * 100$

An ANOVA was performed on all the sub-samples to determine if there were differences with respect to the magnitudes of abnormal volume traded for each announcement type (Zikmund, 2003; and Albright, Winston and Zappe, 2006). In order to improve the approximation of normality, bootstrap techniques were used as well. 
The data analysis performed using the bootstrap technique was almost the same as that performed in the prior analysis. The only difference between the approaches was in the way that the expected volume turnover (EVT) and abnormal daily cumulative abnormal volume traded (ACAVT) were calculated. Firstly, the data was sampled 5000 times (with replacement) from the original sample to form bootstrap samples. Each bootstrap sample was the same size as the original sample (it contained 63 data points). Sampling with replacement resulted in certain data points being used more than once in the bootstrap sample. Equation 2 was rewritten as follows, to differentiate the bootstrap expected log turnover using an asterisk (*).

$\bar{\tau}_{\mathrm{i}, \mathrm{t}}{ }^{*}=\left(\frac{\sum_{\mathrm{t}=-84}^{\mathrm{t}=-21} \tau_{\mathrm{i}, \mathrm{t}}{ }^{*}}{63}\right)$

The mean expected log turnover was calculated for each bootstrap sample in terms of Equation 6. This formed a bootstrap distribution of the means. The information from this distribution (its shape, mean, and spread) informed the calculation of the bootstrap distribution's mean and bootstrap error.

The bootstrap expected log turnover was then utilised in the calculation of the bootstrap abnormal turnover. In order to maintain consistency, the abnormal volume traded was first calculated for the entire sample. Thereafter the calculation was performed for each sub-sample. Bootstrap t-tests were used to calculate the value of ACAVT and to infer the statistical significance of the results. In the case of ACAVT, a one tail bootstrap t-test was executed on the AVT sample of 21 days. This was followed by ANOVA, to test the difference between the means or medians of the different sub-samples. Finally, as a robustness check, the results obtained from the bootstrap method were compared to the results obtained using the original data sample.

Although the data was sourced and analysed with care, it was noted that not all abnormal returns had corresponding SENS announcements. This implied that either the SENS databases had missing information or that there were other events, which were not SENS related, that had a material impact. The effect of this problem was minimised by using both the McGregor BFANet News database of McGregor BFANet (2009a) and the Imara SP Reid website (Imara SP Reid, 2009). If the corresponding announcement could not be found in either, the data was not analysed further.

\section{Results}

At the point the "event engine" was utilised (24 June 2009), the ALSI (J203) contained 147 companies. The top five abnormal returns of each of these companies were identified, on the basis that these presented the prime opportunities for insider trading. The resulting 735 observations were then examined against the SENS databases to identify the appropriate public announcement associated with the abnormal return. To be prudent, all observations containing more than one (unrelated) SENS announcement in the $t_{-84}$ to $t_{+5}$ period were disqualified as 
confounding data. Also, returns with no related announcements were excluded. This reduced the sample to 142 announcements, categorised as follows:

BEE and governance (10);

Financial structure (19);

Investment or disinvestment (11);

Key personnel (22);

Mergers and acquisitions (15);

Trading updates (48); and

Other (17).

The analysis of the 142 announcements produced 34 that exhibited statistically significant abnormal volume traded; listed in Table 2 below. The table contains the results of three different tests - the evaluation of the equations; the two sample ttest; and the bootstrap test. Table 2 also shows the average daily cumulative volume turnover (ACAVT) and the average daily percentage abnormal volume traded (APAV).

Table 2: Summary of the announcements that exhibited significant ACAVT and APAV

\begin{tabular}{|c|c|c|c|c|c|c|c|c|}
\hline No. & $\begin{array}{c}\text { Share } \\
\text { Code }\end{array}$ & Date & $\begin{array}{c}\text { Equation } \\
\text { ACAVT } \\
\end{array}$ & $\begin{array}{c}\text { Equation } \\
\text { APAV }\end{array}$ & $\begin{array}{c}\text { T-test } \\
\text { ACAVT } \\
\end{array}$ & $\begin{array}{l}\text { T-Test } \\
\text { APAV }\end{array}$ & $\begin{array}{c}\text { Bootstrap } \\
\text { ACAVT }\end{array}$ & $\begin{array}{c}\text { Bootstrap } \\
\text { APAV }\end{array}$ \\
\hline 1 & ASA & $2009 / 03 / 26$ & 0,44143 & $55,49 \%$ & 0,44143 & $55,49 \%$ & 0,43890 & $55,10 \%$ \\
\hline 2 & NHM & $2008 / 08 / 19$ & 0,71968 & $105,38 \%$ & 0,71968 & $105,38 \%$ & 0,72480 & $106,43 \%$ \\
\hline 3 & BVT & $2008 / 11 / 17$ & 0,21823 & $24,39 \%$ & 0,21823 & $24,39 \%$ & $0,21930^{*}$ & $24,52 \%$ \\
\hline 4 & DSY & $2001 / 06 / 29$ & 1,00303 & $172,65 \%$ & 1,00304 & $172,66 \%$ & 1,00580 & $173,41 \%$ \\
\hline 5 & SOL & $2008 / 11 / 28$ & 1,66138 & $426,66 \%$ & 1,66138 & $426,66 \%$ & $1,66720^{* *}$ & $429,73 \%$ \\
\hline 6 & $\mathrm{AXC}$ & $2008 / 02 / 06$ & 1,11927 & $206,26 \%$ & 1,11926 & $206,26 \%$ & 1,11890 & $206,15 \%$ \\
\hline 7 & SPP & $2006 / 06 / 27$ & 0,54298 & $72,11 \%$ & 0,54299 & $72,11 \%$ & 0,54400 & $72,29 \%$ \\
\hline 8 & SPP & $2006 / 02 / 08$ & 0,39372 & $48,25 \%$ & 0,39371 & $48,25 \%$ & 0,39740 & $48,80 \%$ \\
\hline 9 & TRE & $2004 / 11 / 25$ & 1,51413 & $354,55 \%$ & 1,51413 & $354,54 \%$ & $1,50640^{*}$ & $351,05 \%$ \\
\hline 10 & MRF & $2001 / 02 / 27$ & 2,07427 & $695,87 \%$ & 2,07430 & $695,89 \%$ & 2,07340 & $695,18 \%$ \\
\hline 11 & SLM & $2008 / 10 / 01$ & 0,26291 & $30,07 \%$ & 0,26290 & $30,07 \%$ & 0,26460 & $30,29 \%$ \\
\hline 12 & ALT & $2008 / 12 / 17$ & 0,19827 & $21,93 \%$ & 0,19827 & $21,93 \%$ & $0,19100 * * *$ & $21,05 \%$ \\
\hline 13 & NPN & $2008 / 11 / 10$ & 0,36296 & $43,76 \%$ & 0,36296 & $43,76 \%$ & 0,36430 & $43,95 \%$ \\
\hline 14 & TKG & $2009 / 05 / 18$ & 0,66786 & $95,01 \%$ & 0,66787 & $95,01 \%$ & 0,66750 & $94,94 \%$ \\
\hline 15 & $\mathrm{ABL}$ & $2009 / 03 / 31$ & 0,41427 & $51,33 \%$ & 0,41427 & $51,33 \%$ & 0,41290 & $51,12 \%$ \\
\hline 16 & KGM & $2003 / 04 / 01$ & 3,30973 & $2637,78 \%$ & 3,30975 & $2637,83 \%$ & 3,28530 & $2571,70 \%$ \\
\hline 17 & TON & $2003 / 05 / 26$ & 0,39076 & $47,81 \%$ & 0,39075 & $47,81 \%$ & $0,39420 * * *$ & $48,32 \%$ \\
\hline 18 & ALT & $2007 / 10 / 24$ & 0,64456 & $90,51 \%$ & 0,64456 & $90,52 \%$ & 0,65060 & $91,67 \%$ \\
\hline 19 & IMP & $2001 / 03 / 26$ & 0,34298 & $40,91 \%$ & 0,34297 & $40,91 \%$ & 0,34350 & $40,99 \%$ \\
\hline
\end{tabular}




\begin{tabular}{|c|c|c|c|c|c|c|c|c|}
\hline No. & $\begin{array}{c}\text { Share } \\
\text { Code }\end{array}$ & Date & $\begin{array}{c}\text { Equation } \\
\text { ACAVT }\end{array}$ & $\begin{array}{c}\text { Equation } \\
\text { APAV }\end{array}$ & $\begin{array}{c}\text { T-test } \\
\text { ACAVT }\end{array}$ & $\begin{array}{l}\text { T-Test } \\
\text { APAV }\end{array}$ & $\begin{array}{c}\text { Bootstrap } \\
\text { ACAVT }\end{array}$ & $\begin{array}{c}\text { Bootstrap } \\
\text { APAV } \\
\end{array}$ \\
\hline 20 & LON & $2008 / 08 / 06$ & 0,55700 & $74,54 \%$ & 0,55700 & $74,54 \%$ & 0,55440 & $74,09 \%$ \\
\hline 21 & RBW & $2007 / 03 / 22$ & 1,55339 & $372,75 \%$ & 1,55339 & $372,75 \%$ & 1,55600 & $373,98 \%$ \\
\hline 22 & SBK & $2008 / 03 / 27$ & 0,22495 & $25,23 \%$ & 0,22495 & $25,23 \%$ & 0,22220 & $24,88 \%$ \\
\hline 23 & TBS & $2006 / 07 / 07$ & 0,28476 & $32,94 \%$ & 0,28476 & $32,94 \%$ & 0,28400 & $32,84 \%$ \\
\hline 24 & $\mathrm{ACP}$ & $2003 / 09 / 18$ & 2,03974 & $668,86 \%$ & 2,03974 & $668,86 \%$ & 2,04650 & $674,08 \%$ \\
\hline 25 & EXX & $2008 / 02 / 07$ & 0,51440 & $67,26 \%$ & 0,51440 & $67,26 \%$ & 0,51550 & $67,45 \%$ \\
\hline 26 & ILA & $2001 / 08 / 30$ & 5,37710 & $21539,46 \%$ & 5,37710 & $21539,36 \%$ & 5,36870 & $21358,37 \%$ \\
\hline 27 & IMP & $2008 / 08 / 06$ & 0,47857 & $61,38 \%$ & 0,47856 & $61,37 \%$ & 0,47540 & $60,87 \%$ \\
\hline 28 & MTN & $2008 / 10 / 31$ & 0,52813 & $69,58 \%$ & 0,52813 & $69,58 \%$ & 0,52970 & $69,84 \%$ \\
\hline 29 & MUR & $2008 / 11 / 25$ & 0,68567 & $98,51 \%$ & 0,68567 & $98,51 \%$ & 0,68800 & $98,97 \%$ \\
\hline 30 & RBX & $2008 / 10 / 21$ & 1,23732 & $244,64 \%$ & 1,23733 & $244,64 \%$ & 1,24300 & $246,60 \%$ \\
\hline 31 & SPP & $2008 / 10 / 31$ & 0,82032 & $127,12 \%$ & 0,82032 & $127,12 \%$ & 0,81630 & $126,21 \%$ \\
\hline 32 & ATN & $2009 / 04 / 01$ & 1,32610 & $276,63 \%$ & 1,32609 & $276,63 \%$ & 1,32550 & $276,41 \%$ \\
\hline 33 & DRD & $2008 / 01 / 25$ & 0,75903 & $113,62 \%$ & 0,75902 & $113,62 \%$ & 0,75680 & $113,14 \%$ \\
\hline 34 & WHL & $2007 / 12 / 14$ & 0,44828 & $56,56 \%$ & 0,44829 & $56,56 \%$ & 0,44920 & $56,71 \%$ \\
\hline \multicolumn{3}{|c|}{$\begin{array}{l}\text { Mean } \\
\text { Standard deviation } \\
\end{array}$} & $\begin{array}{l}0,97404 \\
1,02951 \\
\end{array}$ & $164,86 \%$ & $\begin{array}{l}0,97404 \\
1,02951 \\
\end{array}$ & $164,86 \%$ & $\begin{array}{l}0,97356 \\
1,02703 \\
\end{array}$ & $164,74 \%$ \\
\hline \multicolumn{9}{|c|}{$\begin{array}{l}* 92,5 \% \text { Confidence level } \\
* * 90,0 \% \text { Confidence level } \\
* * * \text { Negative lower confidence level } \\
\text { All other figures have a } 95 \% \text { confidence level } \\
\text { The p-values for the difference between means/medians tests ranged from } 0,00000 \text { to } 0,03934\end{array}$} \\
\hline
\end{tabular}

The above analysis shows that the results are similar for the three different tests performed i.e. a mean ACAVT of approximately 0,974 and APAV of about 165 percent. The p-values ranged from approximately zero to 0.03934 , indicating that the results are significant.

Table 3: T-test and bootstrap test with the complete and the significant abnormal volume turnover (AVT) sample

\begin{tabular}{|c|c|c|c|c|c|c|c|}
\hline \multirow{2}{*}{$\begin{array}{l}\text { Panel 1 } \\
\text { Sample }\end{array}$} & \multirow[t]{2}{*}{ Sample size } & \multicolumn{3}{|c|}{ T-test } & \multicolumn{3}{|c|}{ Bootstrap test } \\
\hline & & Std Dev & Dist & Stat & SE & LCL & UCL \\
\hline $\begin{array}{l}\text { Complete } \\
\text { sample }\end{array}$ & 2982 & 2,804888 & $\begin{array}{l}\text { Non } \\
\text { Normal }\end{array}$ & 7,7678 & 0,0486 & $-0,0102$ & 0,1787 \\
\hline $\begin{array}{l}\text { Significant } \\
\text { sample }\end{array}$ & 714 & 1,973855 & $\begin{array}{l}\text { Non } \\
\text { Normal } \\
\end{array}$ & 16,4895 & 0,0741 & 0,8256 & 1,1186 \\
\hline \multirow{2}{*}{$\begin{array}{l}\text { Panel 2 } \\
\text { Sample }\end{array}$} & \multicolumn{4}{|c|}{ T-test } & \multicolumn{3}{|c|}{ Bootstrap test } \\
\hline & ACAVT & p-value & APAV & Decision & ACAVT & APAV & Decision \\
\hline $\begin{array}{l}\text { Complete } \\
\text { sample }\end{array}$ & $0,00841643 *$ & 0,000000 & $0,85 \%$ & Reject $\mathrm{H}_{0}$ & 0,0846 & $0,85 \%$ & $\begin{array}{l}\text { Do NOT } \\
\text { Reject } \mathrm{H}_{0}\end{array}$ \\
\hline $\begin{array}{l}\text { Significant } \\
\text { sample }\end{array}$ & $0,9740356^{*}$ & 0,000000 & $164,86 \%$ & Reject $\mathrm{H}_{0}$ & $0,9748 * *$ & $165,06 \%$ & Reject $\mathrm{H}_{0}$ \\
\hline Notes & \multicolumn{4}{|c|}{$\begin{array}{l}\text { * Statistically significant at 5\% level using the Wilcoxon } \\
\text { Signed-Rank Test for Difference in Medians }\end{array}$} & \multicolumn{3}{|c|}{$\begin{array}{l}* * \text { Statistically significant for a } 95 \% \\
\text { confidence level }\end{array}$} \\
\hline
\end{tabular}

The above table presents the comparison between the complete sample and significant sample. It also illustrates the results for the main hypothesis. Since both samples were not normally distributed, the Wilcoxon signed-rank test for difference 
in medians was utilised. The results for the significant sample confirm those presented in Table 3, with a p-value of approximately zero. The p-value for the $\mathrm{t}$ test performed on the complete sample was approximately zero, while the lower confidence level for the bootstrap was $-0,0102$. Therefore, the null hypothesis was rejected when using the difference between medians test on the complete sample, but it could not be rejected when utilising a bootstrap test. The AVCAT for the complete sample was also very close to zero, and the APAV was about 0,9 percent. Therefore, the evidence to reject the null hypothesis for the complete sample was not conclusive.

Table 4 summarises the number of significant ACAVT events and the percentage of ACAVT events per category.

Table 4: Number of significant results per announcement category

\begin{tabular}{l|r|r|c|c|c}
\hline \multirow{2}{*}{ Category } & \multicolumn{3}{|c|}{ Number of significant ACAVT } & \multicolumn{2}{c}{ Percentage significant ACAVT } \\
\cline { 2 - 6 } & No & Yes & Total & No & Yes \\
\hline BEE and Governance & 5 & 5 & 10 & $50,0 \%$ & $50,0 \%$ \\
\hline Financial Structure & 13 & 6 & 19 & $68,4 \%$ & $31,6 \%$ \\
\hline Investment/Disinvestment & 8 & 3 & 11 & $72,7 \%$ & $27,3 \%$ \\
\hline Key Personnel & 19 & 3 & 22 & $86,4 \%$ & $13,6 \%$ \\
\hline Mergers and acquisitions & 9 & 6 & 15 & $60,0 \%$ & $40,0 \%$ \\
\hline Other & 14 & 3 & 17 & $82,4 \%$ & $17,6 \%$ \\
\hline Trading update & 40 & 8 & 48 & $83,3 \%$ & $16,7 \%$ \\
\hline Total & 108 & 34 & 142 & $76,1 \%$ & $23,9 \%$ \\
\hline
\end{tabular}

The table illustrates that the different announcement types had proportionately different numbers of significant ACAVTs associated with them. Half of the qualifying BEE and governance announcements exhibited significant ACAVT, while two out of every five qualifying merger and acquisition announcements showed significant ACAVT. On the other end of the scale, only 13,6 percent of qualifying key personnel announcements reflected significant ACAVT. However, due to the low count of significant ACAVTs in some of the announcements (counts of three), the difference in results could not be statistically verified using a chisquared test.

The entire significant sample was analysed collectively as presented in Table 5. This was done by analysing all of the data, in the 21 day abnormal volume traded detection window. A one-sample t-test and a bootstrap test using the daily abnormal volume turnover (AVT) were executed. In addition, the tests were conducted separately for each of the categories. 
Table 5: T-test and bootstrap test with complete qualifying sample and category subsamples

\begin{tabular}{|c|c|c|c|c|c|c|c|}
\hline \multirow{2}{*}{$\begin{array}{l}\text { Panel 1 } \\
\text { Sample }\end{array}$} & \multirow[t]{2}{*}{ Sample size } & \multicolumn{3}{|c|}{ T-test } & \multicolumn{3}{|c|}{ Bootstrap test } \\
\hline & & Std Dev & Dist & Stat & $\mathbf{S E}$ & LCL & UCL \\
\hline $\begin{array}{l}\text { Complete } \\
\text { sample }\end{array}$ & 2982 & 2,804888 & $\begin{array}{l}\text { Non } \\
\text { Normal }\end{array}$ & 7,7678 & 0,0486 & $-0,0102$ & 0,1787 \\
\hline $\begin{array}{l}\text { BEE and } \\
\text { governance }\end{array}$ & 210 & 1,973404 & $\begin{array}{l}\text { Non } \\
\text { Normal } \\
\end{array}$ & 4,4463 & 0,1352 & 0,1342 & 0,6631 \\
\hline $\begin{array}{l}\text { Financial } \\
\text { structure }\end{array}$ & 399 & 3,25083 & $\begin{array}{l}\text { Non } \\
\text { Normal } \\
\end{array}$ & 4,4264 & 0,1630 & $-0,1294$ & 0,5123 \\
\hline $\begin{array}{l}\begin{array}{l}\text { Investment or } \\
\text { disinvestment }\end{array} \\
\end{array}$ & 231 & 2,702377 & $\begin{array}{l}\text { Non } \\
\text { Normal } \\
\end{array}$ & 1,5362 & 0,1734 & $-0,5414$ & 0,1383 \\
\hline Key personnel & 462 & 3,017895 & $\begin{array}{l}\text { Non } \\
\text { Normal } \\
\end{array}$ & 3,6804 & 0,1405 & 0,0777 & 0,6282 \\
\hline $\begin{array}{l}\text { Mergers and } \\
\text { acquisitions }\end{array}$ & 315 & 1,939898 & $\begin{array}{l}\text { Non } \\
\text { Normal } \\
\end{array}$ & 2,8175 & 0,1101 & $-0,2451$ & 0,1884 \\
\hline Trading update & 1008 & 2,502503 & $\begin{array}{l}\text { Non } \\
\text { Normal } \\
\end{array}$ & 2,6616 & 0,0783 & $-0,0969$ & 0,2113 \\
\hline Other & 357 & 2,741051 & $\begin{array}{l}\text { Non } \\
\text { Normal }\end{array}$ & 1,1047 & 0,1459 & $-0,4468$ & 0,1188 \\
\hline \multirow{2}{*}{$\begin{array}{l}\text { Panel 2 } \\
\text { Sample }\end{array}$} & \multicolumn{4}{|c|}{ T-test } & \multicolumn{3}{|c|}{ Bootstrap test } \\
\hline & ACAVT & p-value & APAV & Decision & ACAVT & APAV & Decision \\
\hline $\begin{array}{l}\text { Complete } \\
\text { sample }\end{array}$ & $0,00841643 *$ & 0,000000 & $0,85 \%$ & Reject $\mathrm{H}_{0}$ & 0,0846\# & $0,85 \%$ & $\begin{array}{l}\text { Do NOT } \\
\text { Reject } \mathrm{H}_{0} \\
\end{array}$ \\
\hline $\begin{array}{l}\text { BEE and } \\
\text { governance }\end{array}$ & $0,3883176^{*}$ & 0,000004 & $47,45 \%$ & Reject $\mathrm{H}_{0}$ & $0,3910 * * *$ & $47,85 \%$ & Reject $\mathrm{H}_{0}$ \\
\hline $\begin{array}{l}\text { Financial } \\
\text { structure }\end{array}$ & $0,1881672^{*}$ & 0,000005 & $20,70 \%$ & Reject $\mathrm{H}_{0}$ & $0,1878 \#$ & $20,66 \%$ & $\begin{array}{l}\text { Do NOT } \\
\text { Reject } \mathrm{H}_{0}\end{array}$ \\
\hline $\begin{array}{l}\text { Investment or } \\
\text { disinvestment }\end{array}$ & $-0,2094459 * *$ & 0,062244 & $-18,90 \%$ & $\begin{array}{l}\text { Do NOT } \\
\text { Reject } \mathrm{H}_{0}\end{array}$ & $-0,2114 \#$ & $-19,05 \%$ & $\begin{array}{l}\text { Do NOT } \\
\text { Reject } \mathrm{H}_{0}\end{array}$ \\
\hline Key personnel & $0,3532457^{*}$ & 0,000116 & $42,37 \%$ & Reject $\mathrm{H}_{0}$ & $0,3542 * * *$ & $42,50 \%$ & Reject $\mathrm{H}_{0}$ \\
\hline $\begin{array}{l}\text { Mergers and } \\
\text { acquisitions }\end{array}$ & $-0,037697 *$ & 0,002420 & $-3,70 \%$ & Reject $\mathrm{H}_{0}$ & $-0,0383 \#$ & $-3,76 \%$ & $\begin{array}{l}\text { Do NOT } \\
\text { Reject } \mathrm{H}_{0}\end{array}$ \\
\hline Trading update & $0,05321984^{*}$ & 0,000029 & $5,47 \%$ & Reject $\mathrm{H}_{0}$ & $0,0540 \#$ & $5,55 \%$ & $\begin{array}{l}\text { Do NOT } \\
\text { Reject } \mathrm{H}_{0}\end{array}$ \\
\hline Other & $-0,1729196^{* *}$ & 0,134654 & $-15,88 \%$ & $\begin{array}{l}\text { Do NOT } \\
\text { Reject } \mathrm{H}_{0}\end{array}$ & $-0,1733 \#$ & $-15,91 \%$ & $\begin{array}{l}\text { Do NOT } \\
\text { Reject } \mathrm{H}_{0}\end{array}$ \\
\hline Notes & $\begin{array}{ll}\text { 1. } & \text { Statistic } \\
& \text { Wilcoxo } \\
& \text { Medians } \\
\text { 2. } & \text { ** Not } \mathrm{s} \\
\end{array}$ & $\begin{array}{l}\text { y significan } \\
\text { Signed-Ran } \\
\text { tistically sig }\end{array}$ & $\begin{array}{l}5 \% \text { level us } \\
\text { est for Diffe } \\
\text { cant for reje }\end{array}$ & in & $\begin{array}{ll}\text { 3. } & \text { *** S } \\
& 95 \% \\
\text { 4. } \quad \begin{array}{l}\text { Not } \\
\text { reject }\end{array}\end{array}$ & $\begin{array}{l}\text { stically sig } \\
\text { fidence lev } \\
\text { tistically si } \\
\mathrm{H}_{0}\end{array}$ & $\begin{array}{l}\text { ant for a } \\
\text { icant for }\end{array}$ \\
\hline
\end{tabular}

In the actual data sample, five out of the seven category samples exhibited significant abnormal volume traded preannouncement according to the nonparametric test, thus rejecting the null hypotheses. The p-values ranged from approximately zero to 0,134654 . However, the bootstrap test indicated that the null hypotheses could only be rejected in two of the seven samples, with the lower confidence levels ranging from $-0,5414$ to 0,1342 . To minimise type I errors, the null hypothesis was conclusively rejected only when both tests reject it. In all other cases, based on the evidence, the null hypothesis could not be rejected.

\section{Discussion of results}

In order to make meaningful comparisons with the results of the other studies, the results, where feasible, were transformed to average daily cumulative abnormal volume turnover (ACAVT) or average daily percentage abnormal volume (APAV) calculated until day $t_{-1}$. Table 6 summarises the results from the different studies reviewed. For consistency, only those studies with empirical results were compared. 
Table 6: Findings of comparable studies

\begin{tabular}{|c|c|c|c|c|c|}
\hline Research paper & Markets & $\begin{array}{c}\text { Sample } \\
\text { size }\end{array}$ & Announce Category & AVACT & APAV \\
\hline $\begin{array}{l}\text { Ajinkya and Jain } \\
\text { (1989) }\end{array}$ & NYSE & $\begin{array}{l}2,000- \\
20,000\end{array}$ & N/A & Simulation & Simulation \\
\hline $\begin{array}{l}\text { Meulbroek } \\
\text { (1992) }\end{array}$ & $\begin{array}{l}\text { NYSE, Nasdaq, } \\
\text { AMEX, CBOT }\end{array}$ & 131 & N/A & Not reported. & $\begin{array}{l}93 \% \\
\text { (0.09 Standard } \\
\text { error) }\end{array}$ \\
\hline $\begin{array}{l}\text { Ryan and Taffler } \\
\text { (2004) }\end{array}$ & LSE & 215 & $\begin{array}{l}\text { Share deals } \\
\text { Interim results } \\
\text { Preliminary results } \\
\text { Bids } \\
\text { Financing } \\
\text { Director share dealing } \\
\text { Analysts } \\
\end{array}$ & \multicolumn{2}{|c|}{$\begin{array}{l}\text { Not reported. However, the rank } \\
\text { order of the different events was } \\
\text { provided instead. }\end{array}$} \\
\hline $\begin{array}{l}\text { Jarrell and } \\
\text { Poulsen (1989) }\end{array}$ & NYSE, AMEX & 161 & Mergers and acquisitions & \multicolumn{2}{|c|}{$\begin{array}{l}\text { Not reported. However, they do } \\
\text { report that } 34.7 \% \text { of the sampled } \\
\text { firms reported significantly greater } \\
\text { than usual volume the day before the } \\
\text { announcement. }\end{array}$} \\
\hline $\begin{array}{l}\text { Ascioglu, } \\
\text { McInish and } \\
\text { Wood (2002) } \\
\end{array}$ & NYSE, Nasdaq & 54 & Mergers and acquisitions & $\begin{array}{l}(5,414+0,960) / 21 \\
\text { (days from data) } \\
=0,3035\end{array}$ & $\begin{array}{l}35,46 \% \\
(10 \% \\
\text { Significance) } \\
\end{array}$ \\
\hline $\begin{array}{l}\text { Keown and } \\
\text { Pinkerton (1981) }\end{array}$ & $\begin{array}{l}\text { NYSE \& } \\
\text { AMEX, } \\
\text { Over The } \\
\text { Counter }\end{array}$ & $\begin{array}{l}101 \\
93\end{array}$ & Mergers and acquisitions & \multicolumn{2}{|c|}{$\begin{array}{l}\text { Not reported. However, } 79 \% \text { of the } \\
\text { acquired firms exhibited higher } \\
\text { volume one week prior to the } \\
\text { announcement date. The increase in } \\
\text { volume traded in this period was } \\
247 \% \text {. }\end{array}$} \\
\hline $\begin{array}{l}\text { Sanders and } \\
\text { Zdanowicz } \\
(1992)\end{array}$ & NYSE, AMEX & 30 & Mergers and acquisitions & \multicolumn{2}{|c|}{$\begin{array}{l}\text { It was difficult to derive ACAVT as } \\
\text { they use two dates, and the difference } \\
\text { between the two dates was not fixed. } \\
\text { However, they do report a CAVT of } \\
0.829 \text { until two days before the } \\
\text { announcement. This figure was not } \\
\text { statistically significant. }\end{array}$} \\
\hline $\begin{array}{l}\text { Arnold et al. } \\
\text { (2006) }\end{array}$ & $\begin{array}{l}\text { CBOE, Phil, } \\
\text { AMEX, Pacific, } \\
\text { NYSE }\end{array}$ & 356 & $\begin{array}{l}\text { Mergers and acquisitions } \\
\text { (non-option sample } \\
\text { reported) }\end{array}$ & $\begin{array}{l}(0,85+0,02) / 20 \\
\text { (days from data) } \\
=0,0435 \\
(1 \% \\
\text { significance) }\end{array}$ & $\begin{array}{l}4,45 \% \\
(1 \% \\
\text { significance })\end{array}$ \\
\hline $\begin{array}{l}\text { Jayaraman, Frye } \\
\text { and Sabherwal } \\
(2001)\end{array}$ & $\begin{array}{l}\text { CBOE } \\
\text { (Chicago Board } \\
\text { Options } \\
\text { Exchange) }\end{array}$ & 33 & $\begin{array}{l}\text { Mergers and acquisitions } \\
\text { (stock sample volume } \\
\text { reported) }\end{array}$ & $\begin{array}{l}0,95 / 30 \text { (days } \\
\text { from data) } \\
=0,031667 \\
(1 \% \\
\text { significance }) \\
\end{array}$ & $\begin{array}{l}3,22 \% \\
(1 \% \\
\text { significance })\end{array}$ \\
\hline $\begin{array}{l}\text { Cao, Chen and } \\
\text { Griffin (2005) }\end{array}$ & CBOE & 78 & $\begin{array}{l}\text { Mergers and acquisitions } \\
\text { (stock sample volume } \\
\text { reported) }\end{array}$ & & $\begin{array}{l}36,8 \% \\
(5 \% \\
\text { significance) }\end{array}$ \\
\hline Chae (2005) & NYSE, AMEX & 22,930 & Acquisition & $\begin{array}{l}4,1277(1 \% \\
\text { Significance) }\end{array}$ & $6,687 \%$ \\
\hline & & 11,255 & Target & $\begin{array}{l}18,2416(1 \% \\
\text { Significance) }\end{array}$ & $8,360,383,816 \%$ \\
\hline & & 330 & Moody's & $\begin{array}{l}3,7902(10 \% \\
\text { Significance) }\end{array}$ & $4,327 \%$ \\
\hline & & 34,515 & All & $\begin{array}{l}8,7867 \\
\text { (Weighted } \\
\text { Average,) }\end{array}$ & $654,538 \%$ \\
\hline
\end{tabular}




\begin{tabular}{|c|c|c|c|c|c|}
\hline Research paper & Markets & $\begin{array}{c}\text { Sample } \\
\text { size }\end{array}$ & Announce Category & AVACT & APAV \\
\hline This study & JSE & $\begin{array}{l}10 \\
19 \\
11 \\
22 \\
15 \\
48 \\
17 \\
142\end{array}$ & $\begin{array}{l}\text { BEE and governance } \\
\text { Financial structure } \\
\text { Investment or } \\
\text { disinvestment } \\
\text { Key personnel } \\
\text { Mergers and acquisitions } \\
\text { Trading update } \\
\text { Other } \\
\text { Complete sample }\end{array}$ & $\begin{array}{l}0,3883176^{*} \\
0,1881672 \\
-0,2094459 \\
0,3532457^{*} \\
-0,037697 \\
0,05321984 \\
-0,1729196 \\
0,00841643 \\
* 5 \% \\
\begin{array}{l}\text { Significance } \\
\text { level; other } \\
\text { results in the } \\
\text { study are not } \\
\text { significant, }\end{array}\end{array}$ & $\begin{array}{l}47,45 \% * \\
20,70 \% \\
-18,90 \% \\
42,37 \% * \\
-3,70 \% \\
5,47 \% \\
-15,88 \% \\
0,85 \%\end{array}$ \\
\hline
\end{tabular}

The complete sample of 142 companies used in this study was comparable to the sample sizes in the other studies. However, the sample sizes for the individual announcement categories in this study were low (except for the trading update category, they are all below 25). The smallest sample size used by the other researchers was 30 . This justified the utilisation of the bootstrap test.

The wide range of results obtained indicated that there were significant amounts of variability in the way the different researchers qualified and analysed their data. However, it must be noted that with the exception of Sanders and Zdanowicz (1992), all the researchers detected significant abnormal volume traded prior to the related announcement.

The results of this study reflected differences per announcement type. The results obtained from the complete sample indicated that there was no significant abnormal volume traded, thus confirming the findings of Sanders and Zdanowicz (1992). The same deduction was applicable to the following sub-samples: financial structure; investment or disinvestment; mergers and acquisitions; trading update; and other. The BEE and governance; and key personnel categories, however, did exhibit significant abnormal volume traded in the pre-announcement period.

The methods of constructing the sample had a huge influence. The choice of the event window, and the rules used to qualify an event as being acceptable, varied across the different researchers. The method of treating confounding events and the way these were used to disqualify events from the sample also influenced the results. BEE and governance was a uniquely South African construct. The results also indicated the perceived importance of leadership in South Africa. It appears as though South African investors believe that the performance of companies is highly dependent on leadership. Changes in leadership and announcements relating to BEE and governance did have a significant impact on companies - a situation which could have been exploited by insiders for profit. Another possible 
explanation was that the information about these types of announcements leaked out more easily, compared to other types.

The sample could have been constructed such that it minimised either type I or type II errors, or something in between. This obviously influences the results. This study minimised type I errors, thus was conservative in declaring significant preannouncement abnormal volume traded.

It was difficult to generalise about possible insider trading activities. The amount of pre-announcement activity was very dependent on the shares and announcements analysed and the perceived magnitude of the announcement. It was therefore felt, that from a JSE and FSB perspective, it was more intuitive and more useful to analyse insider trading activities individually in addition to collectively as a complete sample.

In their study Jarrell and Poulsen (1989) did not calculate ACAVT. However, they found that 35 percent of their mergers and acquisitions sample exhibited ACAVT pre-announcement. Table 4 reports similar results for this study. When the complete sample was considered, ACAVT pre-announcement was detected in 24 percent of the sample. However, when the mergers and acquisitions sub-sample was considered, ACAVT was significant 40 percent of the time. This was comparable to the findings of Jarrell and Poulsen (1989).

The figure of a 24 percent prevalence of significant ACAVT pre-announcement seems high. However, this figure is biased by a sampling method that was geared to having the highest probability of detecting significant pre-announcement ACAVTs in the qualifying sample. Therefore, a high prevalence of ACAVT was to be expected. If all qualifying SENS announcements were to be analysed, the sample size would have been much larger, and the incidence of significant ACAVTs would have been lower.

Based on the evidence obtained, it was concluded that insider trading was not endemic or pervasive on the JSE, as this must also be considered in the context of the sample used - which was constructed to maximise the probability of detecting possible insider trading activities.

\section{Conclusions and recommendations}

It would be naive to think that the techniques proposed here would provide all the answers with respect to the detection of insider trading. This research is considered as a tool, which forms part of the toolbox of complimentary techniques to detect, diagnose, analyse, and prosecute insider trading.

The techniques utilised in this study would be able to support the process of identifying possible insider trading activities by determining the level of preannouncement abnormal volume traded around an announcement. This, together with share price analysis, should provide compelling evidence to delve deeper into suspicious activities. However, any sample has to be chosen carefully in order to 
properly characterise the JSE. When evaluating a complete sample, rather than individual announcements, the following issues would have to be carefully considered:

- Sample selection: Issues such as the period of the study, the number of shares that would be analysed, the information sources, the definition of confounding events, and the removal of confounding events.

- Event window: At this stage, no guidelines could be found on how to construct an event window. The decisions made on the window period used to benchmark and detect abnormal volumes would influence the results.

\section{8. $\quad$ Research limitations}

The study covered the period from 01 January 2000 to 24 June 2009, and was therefore not representative of all time periods. Furthermore, the research only considered shares in the JSE ALSI as at 24 June 2009.

The "event engine" developed by Muller and Ward (2009) was used to generate the top five abnormal returns for companies on the All Share Index. Therefore, the analysis did not analyse all of the SENS announcements. The sample generated was biased in that it was geared to increase the probability of detecting significant preannouncement abnormal volume traded.

The research only considered SENS announcements. There may have been other announcements made on other platforms that were not analysed. Insider trading activities could have also preceded these announcements.

Due to the limitations of the statistical model used, only single announcements could be analysed. Therefore, the research ignored compound effects of multiple announcements. The analysis of these multiple announcements could have materially affected the results.

Only shares were considered for this research. Options, derivatives, and other asset classes were considered beyond the scope for this research. These asset classes could be subject to insider trading activities as well.

This research focused on the analysis of volume traded pre-announcement. However, in order to obtain a more complete analysis, one would need to consider the complementary movement of share prices as well.

\section{Recommendations for further research}

The SENS announcements contain additional information such as the names of the lawyers, accountants, investment bankers, and financiers, etc. involved with the announcement. According to the Act, these parties would be considered as insiders (RSA, 2004). It would be interesting to investigate whether particular parties are 
consistently involved when there is significant pre-announcement activity, and to determine whether there are any 'serial offenders'.

In the United States of America researchers have investigated significant preannouncement abnormal volume in trading options of company shares. They confirmed that the magnitude of abnormal activity was more pronounced than in the case of shares (Arnold et al., 2006; Jayaraman, Frye and Sabherwal, 2001; and Cao, Chen and Griffin, 2005). Thus, it seems as though the derivatives market cannot be ignored (even though it is not as well developed in South Africa) if a more complete picture of insider trading is to be developed.

Liquidity could play a role in characterising insider trading. It is therefore recommend that the relationship between liquidity and preannouncement volume activity be investigated. Smaller companies on the JSE and the Alt-X exchange could also be examined.

The research investigated abnormal volume activity around SENS announcements. Therefore, other types of announcements - such as analysts' reports and press announcements were not considered. These announcements could also have a bearing on the results.

At this stage the effectiveness of the insider trading penalties in South Africa is not known (especially when compared to the rest of the world). There have been some international studies, but none published from a South African perspective. It would be useful to benchmark the penalties imposed by countries in the rest of the world and their success in curbing insider trading with those in South Africa. The findings of this study could be used to make recommendations to the JSE and FSB.

Finally, the techniques presented in this paper are of a diagnostic nature. They would be useful investigative tools for insider trading activities after the fact i.e. retrospectively. More proactive models should be investigated. These would be helpful in the detection of possible insider trading activities earlier in the process, through the implementation of an early warning system. This would allow the JSE and FSB to preside over such cases and prosecute offenders whilst the details are still fresh. 


\section{References}

Ajinkya, B and Jain, P (1989): "The Behavior of Daily Stock Market Trading Volume", Journal of Accounting and Economics, 11(4), 331.

Albright, S C, Winston, W L and Zappe, C J (2006): Data Analysis and Decision Making with Microsoft Excel, 3e ed., Mason: Thompson - South Western.

Arnold, T, Erwin, G, Nail, L and Nixon, T (2006): "Do Option Markets Substitute for Stock Markets? Evidence from Trading on Anticipated Tender Offer Announcements", International Review of Financial Analysis, 15(3), 247.

Ascioglu, N A, McInish, T H and Wood, R A (2002): "Merger Announcements and Trading", The Journal of Financial Research, 25(2), 263-278.

Bhattacharya, U and Daouk, H (2002): "The World Price of Insider Trading", The Journal of Finance, 57(1), 75-108(34).

Cao, C, Chen, Z, and Griffin, J M (2005): "Informational Content of Option Volume Prior to Takeovers", The Journal of Business, 78(3), 1073-1109.

Chae, J (2005): "Trading Volume, Information Asymmetry, and Timing Information", The Journal of Finance, 60(1), 413-442.

Chordia, T, Subrahmanyam, A and Anshuman, V R (2001): "Trading Activity and Expected Stock Returns", Journal of Financial Economics, 59(1), 3.

Fidrmuc, J P, Goergen, M and Renneboog, L (2006): "Insider Trading, News Releases, and Ownership Concentration", The Journal of Finance, 61(6), 2931-2973(43).

FSB (2009): Financial Services Board South Africa: Report on the Activities of the Insider Trading Directorate, FSB, Pretoria.

Givoly, D and Palmon, D (1985): "Insider Trading and the Exploitation of Inside Information: Some Empirical Evidence", The Journal of Business, 58(1), 69-87.

Imara SP Reid. JSE News[online], Imara SP Reid. Available from https://www.imaraspreid.co.za/snet/imara/ (accessed 02 October 2009):.

Jarrell, G A and Poulsen, A B (1989): "Stock Trading before the Announcement of Tender Offers: Insider Trading or Market Anticipation?" Journal of Law, Economics, and Organization, 5(2), 225248.

Jayaraman, N, Frye, M B and Sabherwal, S (2001): "Informed Trading Around Merger Announcements: An Empirical Test Using Transaction Volume and Open Interest in Options Market", Financial Review, 36(2), 45-74.

Keown, A J and Pinkerton, J M (1981): "Merger Announcements and Insider Trading Activity: An Empirical Investigation", Journal of Finance, 36(4), 855-869.

McGregor BFANet, Analyser News Company Information[online], McGregor BFANet. Available from http://secure.mcgbfa.com/CompanySearchDefault.aspx?Token=d4vaAxFD5ouFgwcpLaDxWw\%3d\%3 dandClientID=85andConModule=124andicon=http://secure $. \mathrm{mcgbfa} . \mathrm{com} / \mathrm{images} / 1 \mathrm{x} 1$ trans. .gifandiconid $=90$ andReturnURL=/Station/News/NewsList.aspxandListURL=/Station/News/NewsList.aspx (accessed 02 October 2009).

McGregor BFANet, Analyser Price Data Company Information[online], McGregor BFANet. Available from 
http://secure.mcgbfa.com/CompanySearchDefault.aspx?Token=1CJ21CpWvNGtAy1aYe8W/w\%3d\%3 dandClientID=85andConModule=125andicon=http://secure $\cdot \mathbf{m c g b f a} . \mathrm{com} / \mathrm{images} / 1 \mathrm{x} 1 \mathrm{trans}$. gifandiconid $=84$ andReturnURL=/Station/PriceData/PriceDataDetail.aspx (accessed 02 October 2009).

McWilliams, A and Siegel, D (1997): "Event Studies in Management Research: Theoretical and Empirical Issues", The Academy of Management Journal, 40(3), 626-657.

Meulbroek, L K (1992): "An Empirical Analysis of Illegal Insider Trading", The Journal of Finance, 47(5), 1661-1699.

Mordant, N and Muller, C (2003): "Profitability of Director's Share Dealings on the JSE", Investment Analysts Journal, 5717-31.

Morse, D (1981): "Price and Trading Volume Reaction Surrounding Earnings Announcements: A Closer Examination", Journal of Accounting Research, 19(2), 374-383.

Muller, C and Ward, M J D (2009): The Event Study Model, Email Correspondence, RSA (2004) Securities Services Act, 2004. 36.

Ryan, P and Taffler, R J (2004): "Are Economically Significant Stock Returns and Trading Volumes Driven by Firm-specific News Releases?", Journal of Business Finance and Accounting, 31(1), 49-82.

Sanders, R W Jr. and Zdanowicz J S (1992): "Target Firm Abnormal Returns and Trading Volume Around the Initiation of Change in Control Transactions", The Journal of Financial and Quantitative Analysis, 27(1), 109-129.

Van der Plas, F (2007): The Occurrence of Insider Trading in Target Shares of JSE Listed Companies Prior to Takeover Announcements, MBA, Gordon Institute of Business Science.

Wong Kie, A, Sequeira, J M and McAleer, M (2005): "Modelling the Information Content in Insider Trades in the Singapore Exchange", Mathematics and Computers in Simulation, 68(5-6), 417.

Zikmund, W G (2003): Business Research Methods, 7th ed.: Mason: Thompson South-Western. 
J.STUD.ECON.ECONOMETRICS, 2011, 35(1) 